\title{
Новая схема тектонического районирования Бунделкхандского кратона Индийского щита
}

\author{
Слабунов А.И. ${ }^{1}$, Синг В.К. ${ }^{2}$ \\ ${ }^{1}$ Институт геологии КарНЦ РАН, Петрозаводск, slabunov@krc.karelia.ru \\ ${ }^{2}$ Бунделкхандский университет, геологический $p-m$, Джанси, Индия, vinodksingh@bujhansi.ac.in
}

\begin{abstract}
Аннотация. Бунделкхандский кратон Индийского щита подразделяется на три террейна: Центрально-, Северно- и Южно-Бунделкханский. Тектоническое районирование выполнено на основе анализа особенностей развития земной коры каждого из них, а также глубинного строения кратона. Последнее получено по результатам магнито-теллурического зондирования. Центрально-Бунделкханский террейн сложен палеонеоархейскими гранитоидами тоналит-трондьемит-гранодиоритовой (ТТГ) серии, мезо-неоархейским зеленокаменным комплексом, в меньшей степени микроклиновыми гранитами. Его земная кора выделяется относительно низким удельным сопротивлением и мощность около 60 км. Северо-Бунделкханский террейне сложен преимущественно неоархейскими микроклиновыми гранитами, санукитоидами, монцогранитами, редки фрагменты ТТГ и мафитов. Земная кора этот террейна выделяется в виде однородого блока с высоким удельным сопротивлением и имеет мощность около 65-70 км. Южно-Бунделкхандский террейн сложен, главным образом, также микроклировыми гранитами, но здесь идентифицируется присутствие палеоархейских ТТГ, обычны архейские мафит-ультрамафитовые интрузии, сланцевый пояс, единичные массивы неоархейских санукитоидов. Земная кора этот террейна имеет трехчленное строение и мощность около 60 км.
\end{abstract}

Ключевые слова: архей, тектоническое районирование, Бунделкхандский кратон, Индийский щит.

\section{The new tectonic division of the Bundelkhand Craton, Indian Shield}

\author{
Slabunov A.I. ${ }^{1}$, Singh V.K. ${ }^{2}$ \\ ${ }^{1}$ Institute of Geology, Karelian RC, RAS, Petrozavodsk, slabunov@krc.karelia.ru \\ ${ }^{2}$ Department of Geology, Bundelkhand University, Jhansi, India, \\ vinodksingh@bujhansi.ac.in
}

\begin{abstract}
The Bundelkhand Craton of the Indian Shield is divided into three terrains: Central, Northern and Southern Bundelkhand. The tectonic division is based on analysis of the crustal evolution and deep structure of each terrain. Analysis of the deep structure is based on the results of magnetotelluric studies. The Central Bundelkhand terrain consists of Paleo-Neoarchean tonalite-trondhjemite-granodiorite (TTG) granitoids, a Meso-Neoarchean greenstone complex and lesser K-rich granites. It's approximately $60 \mathrm{~km}$ thick earth crust displays relatively low resistivity. The North Bundelkhand terrain consists dominantly of Neoarchean K-rich granites, sanukitoids and monzogranites; TTG and mafic rock fragments are scarce. The $65-70 \mathrm{~km}$ thick earth crust of this terrane is a homogeneous high-resistivity block. The Southern Bundelkhand terrain consists mainly of K-rich granites and smaller quantities of Paleoarchean TTG; Archean mafic-ultramafic intrusions are common; a schist belt and scarce Neoarchean sanukitoid massifs occur. The Earth crust of this terrain consists of three units and is about $60 \mathrm{~km}$ thick.
\end{abstract}

Key words: Archean, tectonic division, terrain, Bundelkhand Craton, Indian Shield.

\section{Introduction}

The Indian Shield consists of several segments of Archean cratons, i.e. Bundelkhand-Aravalli, Dharwar, Bastar, and Singhbhum cratons (Fig. 1 a). The ENE-WSW trending Central Indian Tectonic Zone (CITZ) or the Narmada Son Lineament is a major lineament, which separates the Dharwar, Bastar, Singhbhum cratons as a southern block (Ramakrishnan and Vaidyanadhan, 2010). The northern block, consisting of the Aravalli and Bundelkhand cratons, is also divided by the NE-SW trending Great Boundary Fault to the west and the east, respectively (Ramakrishna and Vaidyanadhan, 2010; Roy, Purohit, 2018).

The Bundelkhand Craton has long been considered as a big granite massif with other rock inclusions alienated along the Bundelkhand Tectonic Zone form two areas (Ramakrishna \& Vaidyanadhan, 2010). First time, Singh \& Slabunov (2015) illustrate that it is much more similar structurally to other cratons than it was assumed before, but the contribution of Neoarchean K-rich granitoids is considerable. The new 

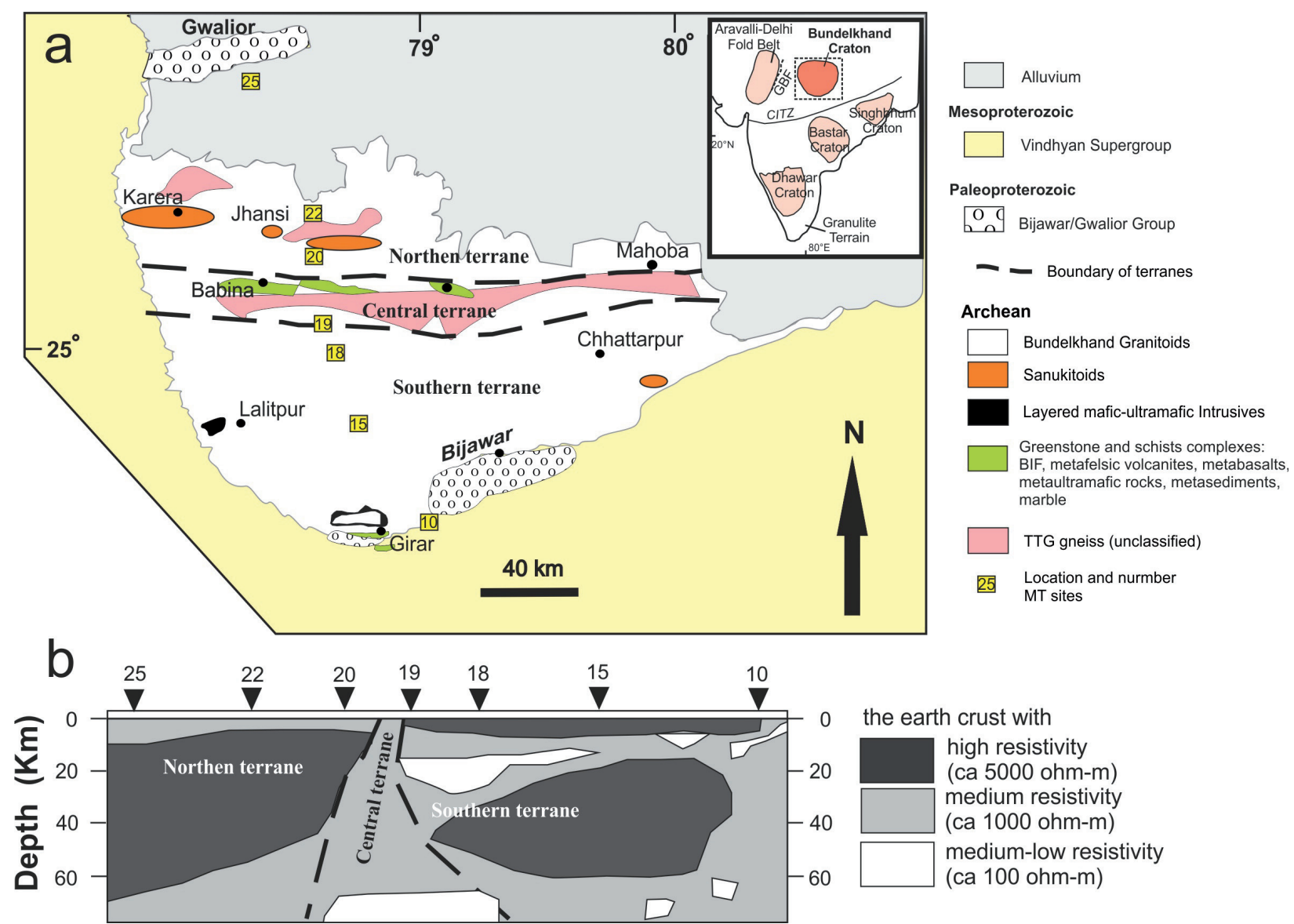

Fig. 1. (a) Map showing the tectonic division of the Bundelkhand Craton (compiled using: Singh \& Slabunov, 2015; Slabunov \& Singh, 2018; Slabunov et al., 2018; Joshi \& Slabunov, 2019), the inset shows the cratonic blocks of the Indian Shield (Ramakrishna and Vaidyanadhan, 2010); (b) scheme of the deep crustal structure of the Bundelkhand Craton along the profile indicated in Fig. 1 a by dots from 10 to 25 (modified after Gokarn et al., 2013).

Рис. 1. (а) Схема тектонического районирования Бунделкхандского кратона (составлена с использованием: Singh \& Slabunov, 2015; Slabunov \& Singh, 2018; Slabunov et al., 2018; Joshi \& Slabunov, 2019; Singh et al., 2019a), на врезке показаны кратоны Индийского щита (Ramakrishna and Vaidyanadhan, 2010); (b) схема глубинного строение земной коры Бунделкхандского кратона кратона по профилю обзоначенному на рис 1 а точками от 10 до 25 (на основе: Gokarn et al., 2013).

geological data on the Bundelkhand Craton and its deep crustal structure, published in the past few years (Slabunov \& Singh, 2018; Singh et al., 2019 a) and based on magnetotelluric sounding (Gokarn et al., 2013), provide a basis for the tectonic division of the craton and recognition of the Central, Northern, and Southern Bundelkhand terraines.

\section{Terrains of the Bundelkhand craton}

The Central Bundelkhand terrain, composed mainly of granite-greenstone complexes, occurs in the Babina-Mauranipur-Mahoba area (Fig. 1a; Mondal et al., 2002; Saha et al., 2016, Singh \& Slabunov, 2015; Kaur et al., 2016; Verma et al., 2016; Slabunov \& Singh, 2018). They comprise Paleo-Neoarchean TTG, Paleoarchean oceanic rocks (Singh et al., 2019b), Meso-Neoarchean greenstone rocks, and a Neoarchean granodiorite-granite suite (Singh et al., 2019a). The greenstone rocks occur mostly in the Babina and Mauranipur belts, with an E-W strike direction known as Bundelkhand Tectonic Zone (Ramakrishna \& Vaidyanadhan, 2010). These belts are composed of a Mesoarchean (ca. $2.81 \mathrm{Ga}$ ) sequence of mafic to ultramafic lava, felsic volcanics, metasedimentary rocks (BIFs) and Neoarchean felsic volcanics (lava and dykes) (Singh \& Slabunov, 2015 a, 2016). There are fragments of Paleoarchean oceanic mafic-ultramafic 
rocks here (Singh et al., 2019b). Neoarchean (2542 $\pm 17 \mathrm{Ma}$ ) felsic volcanics (lava) in the Babina belt show a Sm-Nd model age of $3.14 \mathrm{Ga}$; it means that these rocks are contaminated by the existing older crust (Singh \& Slabunov, 2015). The 2557 \pm 33 Ma felsic volcanics (dykes) in the Mauranipur belt (Slabunov \& Singh, 2018) also show their mixing with Mesoarchean rocks as they contain inherent zircons there. K-rich granitoids cut TTG and greenstone belts and commonly form big massifs (Singh \& Slabunov 2015; Singh et al., 2019a). Local positive gravity anomalies in the Central terrain are clearly correlated with maficultramafic rocks from the Central Bundelkhand greenstone complex (Gokarn et al., 2013), which have a thin surface cover with K-rich granitoids. The results of magnetotelluric sounding show that the Earth crust of the Central Bundelkhand terrain (Fig. $1 \mathrm{~b}$ ) is a narrow $\sim 20-25 \mathrm{~km}$ thick zone with relatively low resistivity over the entire thickness of about $60 \mathrm{~km}$ (Gokarn et al., 2013). The $200 \mathrm{~km}$ long E-W trending central terrane is a major structural feature in the craton, which stretches from Babina to Mahoba via Mauranipur and apparently divides the Northern and Southern terrains.

The Northen Bundelkhand terrain, located north of the Central Bundelkhand granite-greenstone terrain (Fig. 1a), consists mainly of K-rich granites with a visible contribution of sanukitoids (Joshi et al., 2017), monzogranites and granodiorites. There are big strongly deformed orthoamphibolite (metagabbro) bodies also exist in this terrain have cross-cut relation with K-rich granitoids. They make up the bulk of the 2577-2560 Ma sanukitoids massifs situated in this part of the terrain (Joshi et al., 2017; Singh et al., 2019 b). The porphyritic micromonzonite-granite massifs occur as subvolcanic-plutonic rocks in this terrain (Singh et al., 2019 a). Magnetotelluric sounding has shown that the Northern Bundelkhand terrain (Fig. 1b) is a homogeneous block with high crustal resistivity to a depth of $65-70 \mathrm{~km}$ (Gokarn et al., 2013). It has a well-defined boundary with the Central Bundelkhand terrain.

The Southern Bundelkhand terrain consists mainly of Neoarchean K-rich granitoids with a minor volume of a schist complex, TTG, sanukitoids and mafic-ultramafic layered intrusion (Fig. 1a). The Girar schist (metasedimentary) belt consists of two groups of rocks: (i) quartzite, (ii) BIFs, minor amount of dolomitic marble and chlorite schist lenses exist near the quartzite/BIF boundary (Singh \& Slabunov, 2016; Sabunov et al., 2017). The quartzites display low-grade metamorphism of fuchsite- and hematite- bearing quartz arenite with thick meta-argillite (schist) laminae and lesser quartz pebble conglomerates (Singh \& Slabunov, 2016). BIF consists of thick-bedded quartz and hematite with magnetite. The quartzites of the Girar schist (metasedimentary) belt consist of 3.43 and $3.25 \mathrm{Ga}$ detrital zircons which evident for the oldest granitoids (may be TTG) occur on this terrain (Slabunov et al., 2017). The southern terrain exposes a large intrusion, presumably a lopolith, known as the Ikauna complex (Slabunov et al., 2018). These mafic-ultramafic rocks lie among the Archean rocks of Bundelkhand granitoids, which apparently cut them, showing the lower levels of their age as Archean. This intrusion indicates the influence of a mantle plume on the continental crust. The Girar metasedimentary belt was apparently formed at that time. A low-gravity field in the central part of the Southern terrain (Gokarn et al., 2013) predetermined by the big role of K-rich granitoids here. Magnetotelluric sounding has shown that the Earth crust of the Southern Bundelkhand terrain consists of three units (Fig. 1b): a thin upper unit, a thick lower unit with high resistivity and a low resistivity zone (Gokarn et al., 2013). The Earth crust of this terrain is slightly thinner (about $60 \mathrm{~km}$ ) than that of the northern terrain.

\section{Conclusions}

The Bundelkhand craton can be subdivided into the Central, Northern, and Southern Bundelkhand terranes on the basis of the combination of its main complexes (TTG, greenstone complexes, maficultramafic, sanukitoids, monzogranite and high-K granites) (Fig. 1a) and the geophysical characteristics (Gokarn et al., 2013). All the terranes display a singular crustal architecture, evolution and geological structure.

We wish to thank the RFBR for a grant (17-55-45005 IND-a) and to the Department of Science and Technology, Gov. of India for grant (INT/RUS/RFBR/P-279). This work is a contribution to the project of KarRC RAS A18-118020290085-4. 


\section{Reference}

1. Joshi K. B., Bhattacharjee J., Rai G., Halla J., Ahmad T., Kurhila M., Heilimo E., Choudhary A. K. The diversification of granitoids and plate tectonic implications at the Archaean-Proterozoic boundary in the Bundelkhand craton, Central India. In: Halla, J., Whitehouse, M.J., Ahmad, T., Bagai, Z. (eds) Crust-Mantle Interactions and Granitoid Diversification: Insights from Archaean Cratons. Geological Society, London, Special Publications 449. 2017. P. 123-157.

2. Joshi K.B., Slabunov. A.I. Neoarchean sanukitoids from the Karelian and Bundelkhand cratons: comparison of composition, regional distribution and geodynamic setting // Transactions of Karelian Research Centre of Russian Academy of Sciences. 2019. V. 2. P. 1-21. DOI: 10.17076/geo841.

3. Gokarn S.G., Rao C.K., Selvaraj C., Gupta G., Singh B.P. Crustal evolution and tectonics of the Archean Bundelkhand craton, Central India // Journal of the Geological Society of India. 2013. V. 82. P. 455.

4. Kaur P., Zeh A., Chaudhri N., Eliyas N. Unravelling the record of Archaean crustal evolution of the Bundelkhand Craton, northern India using U-Pb zircon-monazite ages, Lu-Hf isotope systematics, and whole-rock geochemistry of granitoids // Precambrian Research. 2016. V. 281. P. 384-413.

5. Mondal M.E.A., Goswami J.N., Deomurari M.P., Sharma, K.K. Ion microprobe 207Pb/206Pb ages of zircons from the Bundelkhand massif, northern India: implications for crustal evolution of the Bundelkhand-Aravalli protocontinent //Precambrian Research. 2002. V. 117. P. 85-100.

6. Ramakrishnan M., Vaidyanadhan R. Geology of India. Geological Society of India. 2010. 556 p.

7. Roy A.B., Purohit R. Indian Shield: Precambrian Evolution and Phanerozoic Reconstitution. 2018. Elsiviar. 375 p.

8. Saha L., Frei D., Gerdes A., Pati J.K., Sarkar S., Patoke V., Bhandari A., Nasipur P. Crustal geodynamics from the Archean Bundelkhand Craton, India: constraints from zircon U-Pb-Hf isotope studies // Geological Magazine. 2016. V. 153. P. 179-192.

9. Singh P.K., Verma S.K., Singh V.K., Moreno J.A., Oliveira E.P., Mehta P. Geochemistry and petrogenesis of sanukitoids and high-K anatectic granites from the Bundelkhand craton: Implications for the late-Archean crustal evolution // Journal of Asian Earth Sciences. 2019 a. V. 174. P. 263-282. https://doi.org/10.1016/j. jseaes.2018.12.013.

10. Singh P.K., Verma S.K., Moreno J.A., Singh V.K., Malviya P.K., Oliveira E.P., Mishra S., Arima M., Geochemistry and $\mathrm{Sm}-\mathrm{Nd}$ isotope systematics of metabasalts from the Babina and Mauranipur greenstone belts, Bundelkhand craton: Implications for tectonic setting and Paleoarchean mantle evolution // Lithos. 2019 b. V. 330-331. P. 90-107. https://doi.org/10.1016/j.lithos.2019.02.010.

11. Singh V.K., Slabunov A. The central Bundelkhand Archean greenstone complex, Bundelkhand craton, central India: geology, composition, and geochronology of supracrustal rocks // International Geology Review. 2015. V. 57. P. 1347-1362.

12. Singh V.K., Slabunov A. Two types of Archean supracrustal belts in the Bundelkhand craton, India: Geology, geochemistry, age and implication for craton crustal evolution // Journal of the Geological Society of India. 2016. V. 88. P. 339-348.

13. Slabunov A., Egorova S., Singh V.K., Svetov S., Kumar S. Archean mafic-ultramafic Ikauna layered intrusion, Bundelkhand craton, India: petrography and geochemistry. Arch \& Anthropol. Open Acc.3 (suppl-2). 2018. P. 49-55. doi: 10.31031/AAOA. 2018.03.000557.

14. Slabunov A.I., Singh V.K. Meso-Neoarchaean crustal evolution of the Bundelkhand Craton, Indian Shield: new data from greenstone belts // International Geology Review. 2018. doi.org/10.1080/00206814.2018.1512906.

15. SlabunovA.,Singh V.K.,KumarB.,XiaoliL.Paleoarcheanzircons fromquartzite ofSouthBundelkhandSupracrustal Complex: origin and implications for crustal evolution in Bundelkhand Craton // Central India.Current Science. 2017. V. 112. P. 794-801.

16. Verma S.K., Verma S.P., Oliveira E.P., Singh V.K., Moreno J.A. LA-SF-ICP-MS zircon U-Pb geochronology of granitic rocks from the central Bundelkhand greenstone complex, Bundelkhand craton, India // Journal of Asian Earth Sciences. 2016. V. 118. P. 125-137. 